\title{
Perancangan E-Katalog Produk Berbasis Android pada PT Samudera Jaya Benelli Menggunakan Metode User Centered Design (UCD)
}

\author{
Susana $^{1^{*}}$ \\ ${ }^{1}$ Fakultas Teknologi Informasi, Universitas Widya Dharma Pontianak \\ *Susana@widyadharma.ac.id
}

\begin{abstract}
Technological developments encourage business actors to be more creative in their competition to provide the best services to their consumers. In the field of motor vehicle sales today, however, brochures are still widely used in introducing their products. In light of this, PT Samudera Jaya Benelli wants to have an android-based e-catalog that contains information on their motorbike products so that it will facilitate the process of delivering information to potential customers who visit the showroom. Additionally, the use of e-catalogs can help the company save on the cost of printing brochures and catalogs, which has been the common practice so far. Furthermore, the development of this e-catalog information system uses the User-Centered Designing (UCD) method. The purpose of using UCD is to produce applications that have high use value, which includes the convenience in the usage, management, and effectiveness of the application, as well as the compatibility of the application to users' needs. Therefore, it is expected that this Android-based (mobile) e-catalog application will be able to increase efficiency and provide convenience in displaying products in the form of a digital catalog that has a modern, complete, and simple appearance
\end{abstract}

Keywords: e-catalog, user centered design (UCD), android

\begin{abstract}
Abstrak
Perkembangan teknologi mendorong para pelaku usaha untuk semakin kreatif dalam bersaing memberikan layanan terbaik bagi konsumen. Pada bidang penjualan kendaraan bermotor saat ini, masih banyak menggunakan brosur dalam mengenalkan produk-produk yang dimiliki. PT Samudera Jaya Benelli ingin memiliki sebuah e-katalog berbasis android yang memuat informasi dari produk motor yang mereka miliki sehingga akan memudahkan proses penyampaian informasi kepada calon konsumen yang mengunjungi showroom. Selain itu penggunaan ekatalog dapat membantu perusahaan menghemat biaya pencetakan brosur dan katalog yang dilakukan selama ini. Selanjutnya pengembangan sistem informasi e-katalog ini menggunakan metode User Centered Designing (UCD). Tujuan penggunaan UCD ini adalah untuk menghasilkan aplikasi yang memiliki nilai guna tinggi, termasuk kenyamanan suatu aplikasi dalam penggunaan, pengelolaan, keefektifan, serta kesesuaian aplikasi dengan kebutuhan pengguna. Aplikasi e-katalog berbasis Android (mobile) ini dapat meningkatkan efisiensi dan memberikan kemudahan dalam menampilkan produk berbentuk katalog digital yang memiliki tampilan modern, lengkap dan ringkas (simple).
\end{abstract}

Kata kunci: e-katalog, user centered design (UCD), android

\section{Pendahuluan}

\subsection{Latar Belakang}

PT. Samudera Jaya Benelli merupakan sebuah dealer sekaligus importir franchise motor Benelli yang berasal dari Italia. Sejak 1911, Benelli adalah tentang gairah, warisan, emosi, inovasi, dan lebih dari 100 tahun menghasilkan model inovatif serta teknologi canggih. Sepeda motor Benelli didesain untuk memenuhi berbagai persyaratan bahkan tuntutan pengendara,untuk memastikan pengalaman berkendara terbaik. Sepeda motor Benelli memiliki kepribadian tersendiri dan dapat segera dikenali karena desainnya yang menarik dan terlihat sporty. Konsep desain yang inovatif diterapkan untuk semua model, berkat keahlian tim pengembangan Benelli di Pesaro, Italia. Selain itu, Benelli 
mampu melayani konsumen dengan jaringan distribusi yang luas dan efisien yang mencakup seluruh dunia.

Sejak 2005 Benelli telah menjadi bagian dari kelompok Qian Jiang (QJ), produsen sepeda motor dengan kapasitas terbesar di Cina. QJ memproduksi lebih dari 1.200.000 kendaraan per tahun di pabriknya yang modern di Wenling, sekitar 250 mil dari Shanghai dengan lebih dari 14.000 karyawan. Benelli membuka pintu bagi para penggemar sepeda motor klasik, sekarang dan masa depan berkat model-model baru dengan desain inovatif dan gaya yang tak terlupakan.

Dengan keberagaman model dan desain motor Benelli ini, maka penting untuk membuat katalog yang dapat mencakup keseluruhan produk Benelli ini.

Penelitian ini bertujuan untuk menghasilkan e-katalog dengan basis Android agar mudah diakses baik dari karyawan internal Benelli maupun untuk customer yang ingin mengetahui seluruh model yang disediakan oleh Benelli. Selain itu dengan adanya e-katalog ini juga mengurangi biaya pencetakan katalog yang selama ini sering dilakukan oleh Benelli.

\subsection{Tinjauan Pustaka}

\subsubsection{Penelitian Terdahulu}

Penelitian tentang e-katalog telah banyak dilakukan dalam berbagai bidang, salah satunya adalah penelitian yang dilakukan oleh Nawawi, Hikmah, \& Apriyani. Penelitian tersebut menghasilkan sebuah website berisi informasi bahan pokok untuk memudahkan konsumen dalam memilih produk bahan pokok yang ingin dibeli, selain itu konsumen juga dapat memilih toko-toko tempat pembelian bahan pokok tersebut. Toko-toko pilihan tersebut terbatas hanya untuk toko yang berada di kota Tasikmalaya.[1]

Penelitian yang dilakukan oleh Yulistina \& Arianti menggunakan metode Research and Development (R\&D) menghasilkan e-katalog berbasis web sebagai sistem informasi pemasaran kopi sapit yang membantu masyarakat petani Desa Sapit untuk memasarkan dan sekaligus sebagai ruang publik dalam mengetahui informasi tentang kopi sapit.[2]
Pada 2018 Setyawasih, Sudrajat, Prasaja, \& Sapuguh mengaplikasikan bahasa pemrograman PHP dengan Macromedia Dreamweaver 8.0 untuk menghasilkan katalog produk ponsel berbasis web yang berfungsi untuk menampilkan informasi tentang ponsel serta untuk proses jual beli ponsel secara online.[3]

\subsubsection{Landasan Teori}

Katalog adalah media promosi yang biasanya dicetak dengan berbagai format dan ukuran. Katalog produk merupakan metoda penyimpanan data produk dengan memberikan identifikasi pada setiap data produk kemudian disusun berdasarkan identitas tertentu. Saat ini banyak berkembang katalog produk yang dibuat dengan sistem digital (e-katalog). Katalog digital juga menyediakan fitur untuk menampilkan foto produk secara interaktif sehingga katalog menjadi lebih informatif. Ekatalog menyimpan informasi tentang barang dan jasa yang ditawarkan dan menjadi dasar dalam suatu transaksi. [4]-[6].

Java adalah sebuah bahasa pemrograman dasar dalam sebuah pembuatan aplikasi yang dapat dijalankan di berbagai komputer ataupun berbagai telepon genggam. Java memuat sekumpulan teknologi untuk membuat dan menjalankan perangkat lunak pada komputer standalone ataupun pada lingkungan jaringan. Java 2 adalah generasi kedua dari java platform. Bahasa pemrograman java ini telah digunakan secara luas sebagai bahasa pemrograman umum untuk mengembangkan aplikasi portabel, toolkit dan applet.[6]-[7]

Android merupakan sistem operasi untuk telepon seluler yang berbasis Linux yang menyediakan platform terbuka bagi para pengembang dalam menciptakan aplikasi yang dirancang untuk perangkat bergerak layar sentuh seperti telepon pintar dan komputer tablet. Android memungkinkan pengguna merasakan kualitas layanan terbaik dan memungkinkan pengembang meningkatkan level pengembangan perangkat lunak yang lebih nyaman. [8]-[10]

Android Studio merupakan lingkungan pengembangan perangkat lunak terpaduIntegrated Development Environment (IDE) 
untuk pengembangan aplikasi Android, berdasarkan IntelliJ IDEA.[12]

\section{Metoda Penelitian}

\subsection{Observasi}

Kerja Praktek ini dilaksanakan dengan cara observasi langsung dan wawancara. Observasi yang dilakukan yaitu dengan datang langsung ke lokasi PT Samudera Jaya Benelli dan melihat langsung cara penawaran produk yang dilakukan oleh marketing. Selain observasi, juga dilakukan wawancara kepada marketing untuk mendapatkan informasi yang lebih jelas mengenai proses penawaran produk.

\subsection{Pengumpulan Data}

\subsubsection{Metode wawancara(Interview)}

Metode ini merupakan metode penulisan dan pencatatan langsung melalui pemberian pertanyaan baik secara lisan maupun tertulis kepada orang-orang ataupun pihak yang terkait, yang terlibat langsung maupun tidak langsung dengan objek penelitian.

2.2.2. Metode studi literatur(Library Research)

Metode ini merupakan metode pustaka dengan mencari informasi yang berhubungan dengan penelitian, dapat diperoleh melalui sumber buku-buku, catatan-catatan, atau berkas lainnya.

\subsection{Analisis}

Teknik analisis data yang digunakan penulis dalam merancang system informasi katalog ini adalah dengan menggunakan Unified Modelling Language (UML) yaitu teknik pengembangan sistem yang menggunakan bahasa grafis sebagai alat untuk pendokumentasian dan melakukan spesifikasi pada sistem. Diagram yang digunakan yaitu use case diagram dan activity diagram. Use case diagram adalah diagram yang digunakan untuk menggambarkan hubungan antara sistem dengan actor sedangkan activity diagram adalah diagram yang digunakan untuk menggambarkan alur kerja (aktivitas) pada use case (proses).[13]

\subsection{Perancangan}

Dalam perancangan sistem informasi katalog ini, penulis menggunakan metode
User Centered Design (UCD) dalam desain aplikasi, kemudian menggunakan bahasa pemrograman Java dan aplikasi Android Studio dengan platformMobile serta sistem operasi Android dalam pembuatan aplikasi.

Fase-fase umum dari proses UCD adalah sebagai berikut [14]:

1) Menentukan konteks penggunaan, di mana orang-orang yang akan menggunakan produk diidentifikasi, dilihat dari sisi tujuan dan kondisi di mana produk akan digunakan.

2) Menentukan kebutuhan, menentukan kebutuhan-kebutuhan bisnis dan tujuan pengguna yang harus dipenuhi agar produk yang dihasilkan dapat digunakan dengan baik.

3) Membuat solusi desain sebagai bagian dari proses desain yang harus diselesaikan, membangun sebuah desain antarmuka aplikasi mulai dari konsep hingga menghasilkan sebuah desain yang lengkap.

4) Mengevaluasi hasil desain, yang secara ideal proses evaluasi usability dilakukan pada pengguna secara nyata, sebagai bagian dari rekayasa pengembangan perangkat lunak yang baik.

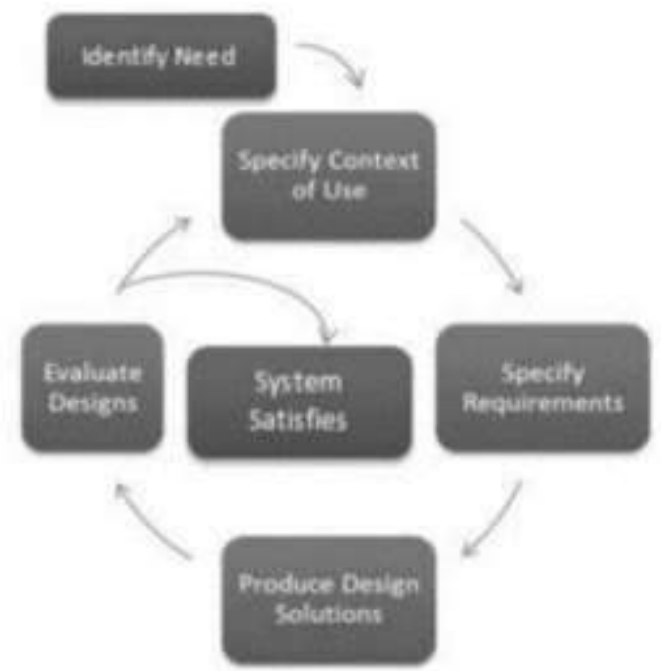

Gambar 1. Siklus hidup fase-fase umum dalam proses UCD [14]

\section{Hasil Penelitian}

\subsection{Analisis Sistem}

Katalog akan digunakan oleh karyawan saat pelanggan datang ke dealer sehingga katalog tersebut bertindak sebagai media 
informasi terperinci yang ditunjukkan kepada calon pelanggan.

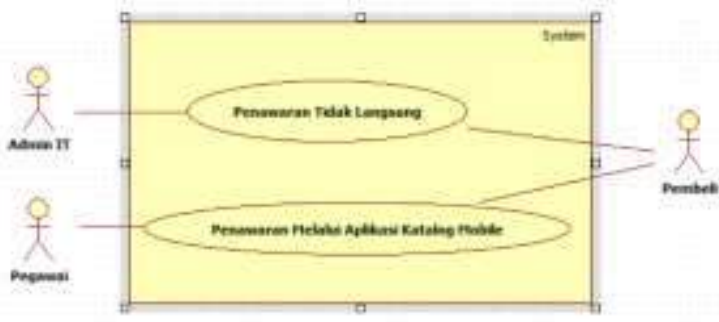

Gambar 2. Use Case Diagram

Karyawan akan menjelaskan produk sambil menunjukkan dan menjalankan aplikasi sistem informasi katalog tersebut kepada calon pelanggan. Hal ini mempermudah karyawan dalam penyampaian informasi sekaligus cepat dan praktis bagi calon pelanggan yang ingin mengecek berbagai produk yang ada tanpa harus berkeliling dealer dan mengecek produk satu per satu.

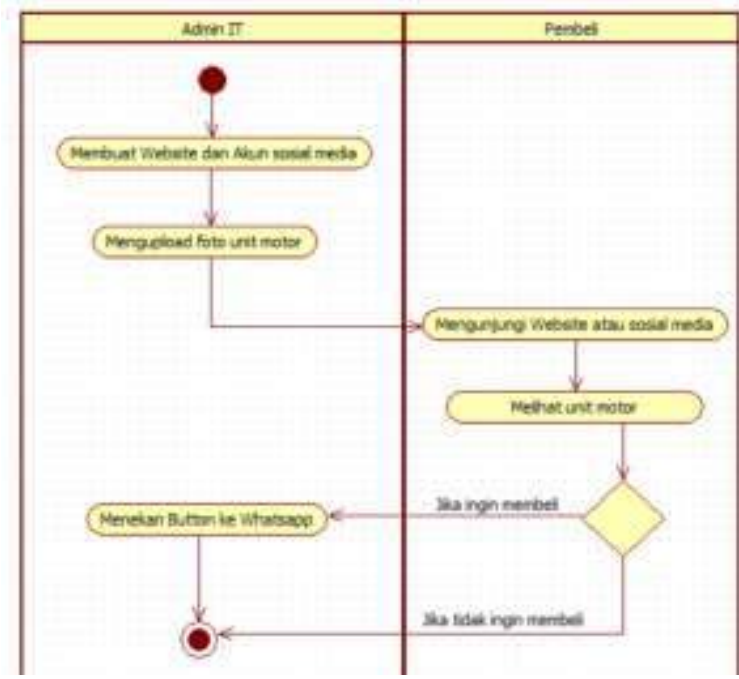

Gambar 3. Activity diagram proses penawaran produk secara tidak langsung

Proses penawaran produk secara tidak langsung terjadi Ketika konsumen mengunjungi website dan akun media sosial yang telah disediakan oleh PT Samudera Jaya Benelli untuk melihat informasi dari berbagai produk yang ada. Promosi jenis ini dapat dilakukan tanpa tatap muka atau bertemu dengan calon konsumen secara langsung. Apabila calon konsumen tertarik dengan produk tertentu dan butuh informasi lebih lanjut, maka calon konsumen dapat langsung menekan tombol Whatsapp yang selanjutkan akan langsung terhubung dengan admin IT.
Pada proses penawaran produk langsung, pembeli mengunjungi showroom/dealer atau pameran yang diselenggarakan oleh Benelli. Kemudian karyawan menawarkan produk melalui aplikasi katalog mobile Benelli yang telah terpasang pada tablet android yang disediakan. Pembeli dapat melihat gambar motor, spesifikasi dari motor, dan daftar fitur yang terdapat pada motor melalui aplikasi tersebut.

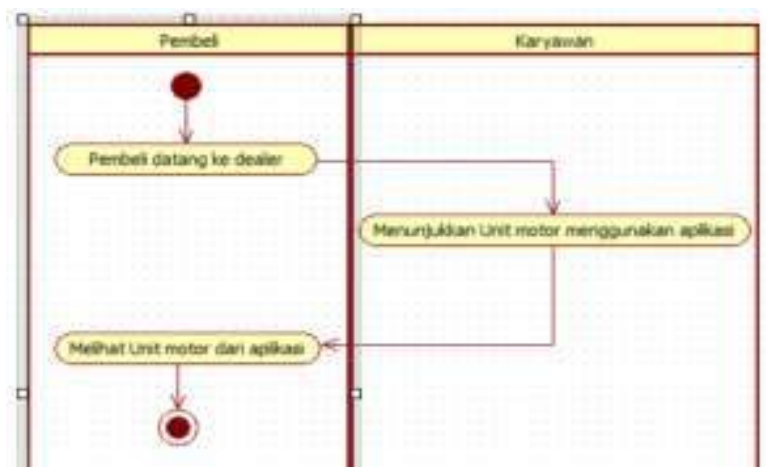

Gambar 4. Activity diagram proses penawaran produk melalui aplikasi katalog mobile

\subsection{Implementasi User Interface Aplikasi}

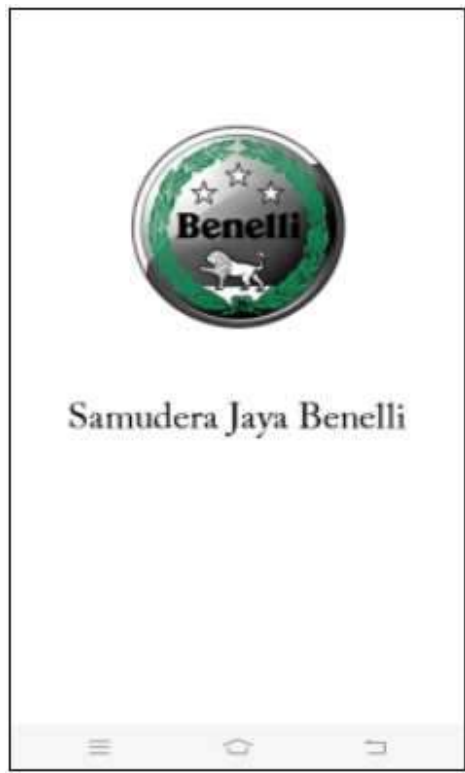

Gambar 5. Splashscreen

Splashscreen berperan sebagai layer yang menunjukkan identitas berupa logo perusahaan dan muncul pertama kali pada saat aplikasi dibuka.

Setelah tampilan splashscreen ini pengguna akan diarahkan ke form utama dalam aplikasi e-katalog ini. Form utama 
mempunyai peranan sebagai pintu utama untuk mengakses form lain. Form utama terdiri dari 5 tombol yang akan mengarahkan user ke tampilan NAKED, SCOOTER, TOURING, LEONCINO, atau CUSTOM.

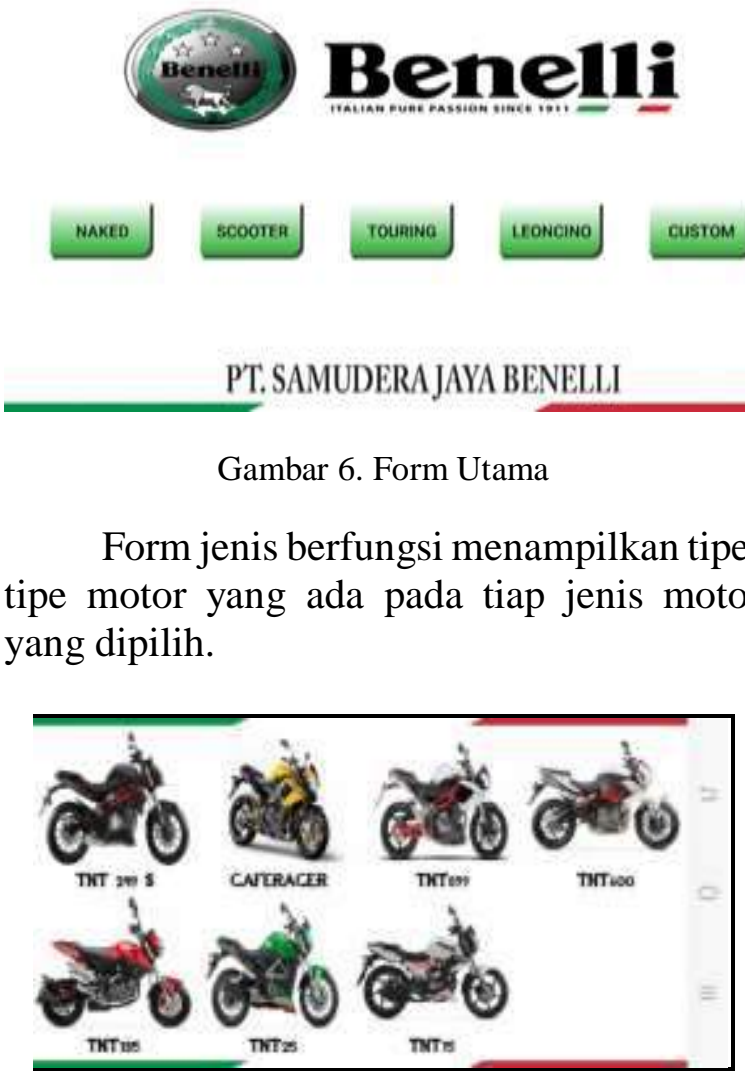

Gambar 7. Form Jenis Naked

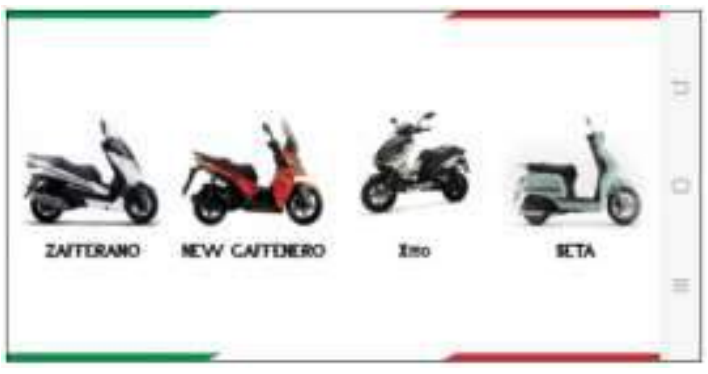

Gambar 8. Form Jenis Scooter

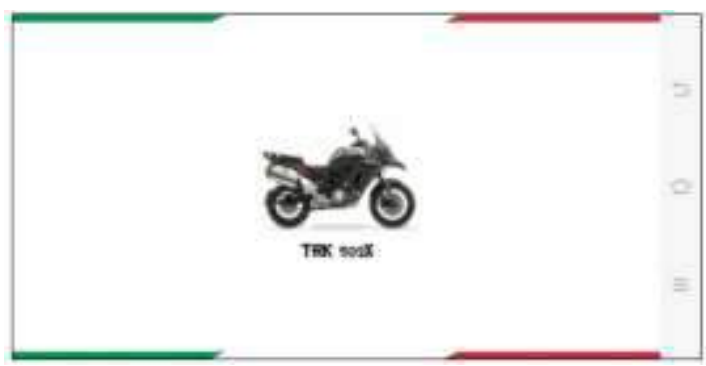

Gambar 9. Form Jenis Touring

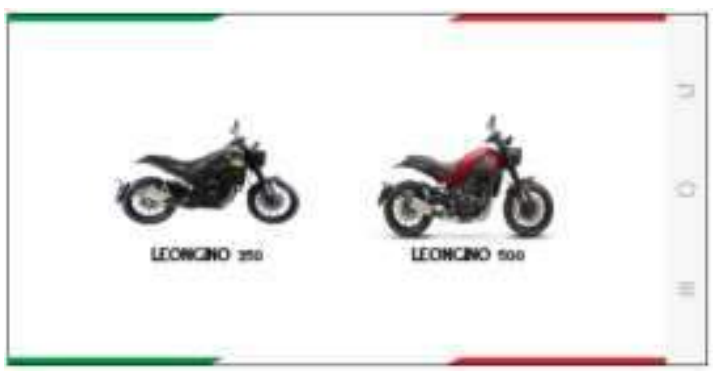

Gambar 10. Form Jenis Leoncino

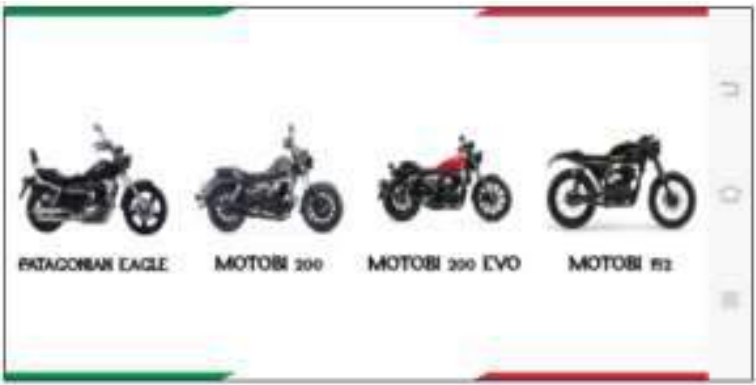

Gambar 11. Form Jenis Custom

Pada form jenis, pengguna dapat memilih tipe motor yang ingin dilihat dan kemudian akan diarahkan ke form tampilan.

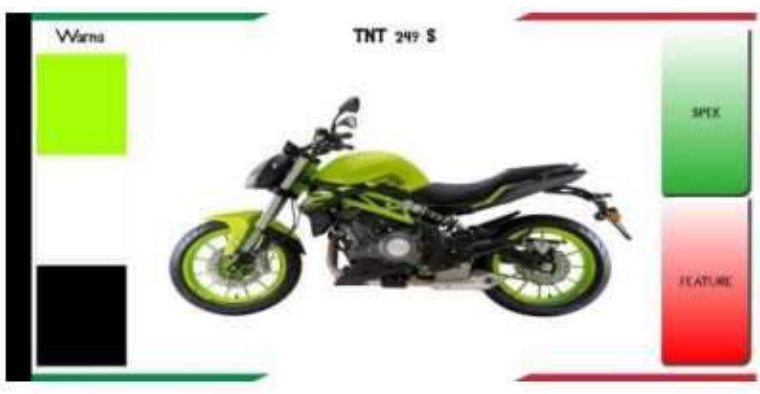

Gambar 12. Form Tampilan Jenis Naked Tipe TNT 249 S Posisi 1

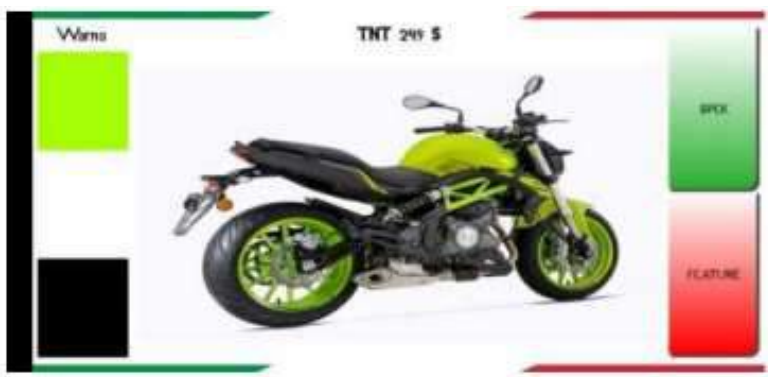

Gambar 13. Form Tampilan Jenis Naked Tipe TNT 249 S Posisi 2

Form Tampilan adalah form yang berisi tampilan model produk dengan pilihan warna di sebelah kiri yang dapat dipilih sesuai yang ingin ditampilkan. Pada Form Tampilan terdapat beberapa tombol, yaitu:

Tombol Warna

Tombol ini memiliki fungsi untuk menampilkan gambar atau tampilan motor 
tersebut dengan pilihan tombol warna yang tersedia.

Tombol Spesifikasi

Tombol ini untuk berfungsi untuk menampilkan tampilan spesifikasi produk yang dipilih sebelumnya.

Tombol Feature

Tombol Feature untuk menampilkan tampilan fitur istimewa yang ingin ditonjolkan pada produk tersebut.

\begin{tabular}{c}
\hline TNT $249 \mathrm{~S}$ \\
Engine \\
* Tipe mesin 2 Silinder, 4 Stroke \\
* Kapasitas mesin $249 \mathrm{cc}$ \\
* Sistem pendinginan Liquid cooled \\
\hline
\end{tabular}

Gambar 14. Form Spesifikasi

Form Spesifikasi ini berfungsi untuk menampilkan informasi spesifikasi secara terperinci pada produk yang dipilih sebelumnya untuk ditunjukkan kepada calon pelanggan.

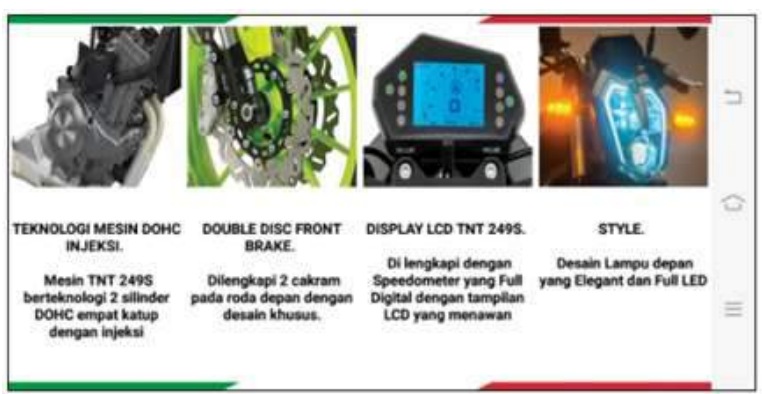

Gambar 15. Form Feature

Form Feature memiliki fungsi untuk menampilkan informasi yang menjadi salah satu bagian penting dan istimewa dari setiap produk. Informasi yang ditampilkan merupakan bagian yang ingin ditonjolkan dari spesifikasi produk secara keseluruhan.

\subsection{Spesifikasi Sistem}

Untuk menjalankan aplikasi yang telah dirancang, dibutuhkan sebuah perangkat mobile yang memadai sesuai dengan syarat minimum yang ditetapkan oleh penulis sendiri. Adapun syarat minimum tersebut: Perangkat Keras
1) Processor atau Chipset Intel Atom ${ }^{\circledR}$ Processor Z2520 1.2 GHz

2) RAM 2GB

3) Storage atau memori internal $16 \mathrm{~GB}$

Perangkat Lunak

Sistem Operasi Android Versi 4 (Jelly Bean)

\section{Kesimpulan}

Berdasarkan berbagai uji coba yang telah dilakukan di PT Samudera Jaya Benelli, dapat disimpulkan bahwa :

1) Aplikasi katalog berbasis Android (mobile) ini dapat diimplementasikan dengan baik pada sistem penawaran produk pada PT. Samudera Jaya Benelli, sehingga dapat melakukan penjualan secara efektif.

2) Aplikasi katalog berbasis Android (mobile) ini dapat membantu PT Samudera Jaya Benelli dalam menghemat biaya pencetakan brosur dan katalog yang digunakan dalam berbagai kegiatan promosi dan penjualan. Sistem yang semula dilakukan dengan manual, kini dapat diwujudkan secara digital. Jadi, dengan adanya aplikasi penjualan berbasis komputer tersebut.

3) Dengan adanya aplikasi katalog berbasis Android (mobile) ini PT Samudera Jaya Benelli dapat meningkatkan efisiensi dan kemudahan dalam menampilkan produk dalam bentuk katalog digital yang memiliki tampilan modern, lengkap dan ringkas (simple).

\section{Saran}

Diharapkan dapat mengadakan pelatihan pengoperasian aplikasi e-katalog ini terhadap staf-staf yang akan menggunakan aplikasi ini sehingga aplikasi ini dapat digunakan secara optimal dalam kegiatan penawaran produk. Aplikasi e-katalog ini juga diharapkan dapat dikembangkan lebih lanjut sesuai kebutuhan, misalnya menampilkan tampilan 3D atau animasi dari produk yang dapat dilihat dari berbagai sudut.

\section{Daftar Pustaka}

[1] H.M. Nawawi, A.B. Hikmah, \& Y. Apriyani, "Perancangan Sistem Informasi Katalog Bahan Makanan Berbasis Web," Konferensi Nasional Ilmu Sosial \& Teknologi (KNiST), pp. 51-55, Mar.2016. 
[2] D. Yulistina,\& B.D. Arianti, "E-Katalog Sebagai Sistem Informasi Pemasaran Kopi Sawit Berbasis Web," EDUMATIC: Jurnal Pendidikan Indonesia, Vol. 3 No. 2 , pp. 45-52, Des. 2019.

[3] R. Setyawasih, et al, "Designing Information Systems of Mobile Phone Catalog Product by Web-based," Journal of Physics: Conference Series, pp.1-6, 2018.

[4] Jasmadi, Cara Praktis Bikin E-Catalog, Semarang: CV. Oxy Consultant, 2018.

[5] Wicaksono, Yudhy, Membuat Macro Lebih Interaktif dengan ActiveX Control, Jakarta:PT Elex Media Komputindo, 2010.

[6] Dongkyu Kim, et al, "A semantic Classification Model for e-Catalogs," in International Conference on E-Commerce Technology,2004, pp 85-92.

[7] S.Ritchie, "Systems programming in Java," in IEEE Micro, vol 17, no.3 , pp. 30-35, May-June 1997.

[8] Sukanto, R. A., \& Shalauddin, M., Rekayasa Perangkat Lunak Terstruktur dan Berorientasi Objek, Bandung : Informatika, 2014.

[9] Nazaruddin, S. H., Pemrograman Aplikasi Mobile Smartphone dan Tablet PC Berbasis Android, Bandung: Informatika, 2012.

[10] S. Guo Hong,"Application Development Research BAsed on Android Platform," $20147^{\text {th }}$ Internasional Conference on Integlligent Computation Technology and Automation, Changsha, 2014, pp. 579-582.

[11] Yudhanto, Y., \& Wijayanto, A., Mudah Membuat dan Berbisnis Aplikasi Android Dengan Android Studio, Jakarta: PT Elex Media Komputindo, 2017.

[12] Herlinah, \& Musliadi, K, Pemrograman Aplikasi Android dengan Android Studio, Photoshop dan Audition, Jakarta: PT Elex Media Komputindo, 2019.
[13] Mulyani, S., Analisis dan Perancangan Sistem Informasi Manajemen Keuangan Daerah (Notasi Pemodelan Unified Modelling Language (UML)), 2th ed. Bandung: Abdi Sistematika, 2016.

[14] Tolle, H., Pinandito, A., Kharisma, A. P., \& Dewi, R. K., Pengembangan Aplikasi Perangkat Bergerak (Konsep dan Implementasi), Malang: UB Press, 2017. 